\title{
Changes in the expression of hepatic genes involved in cholesterol homeostasis in dairy cows in the transition period and at different stages of lactation
}

\author{
G. Schlegel, ${ }^{\star}$ R. Ringseis, ${ }^{*}$ J. Keller, ${ }^{*}$ F. J. Schwarz,† and K. Eder ${ }^{* 1}$ \\ *Institute of Animal Nutrition and Nutrition Physiology, Justus-Liebig-University Giessen, Heinrich-Buff-Ring 26-32, D-35392 Giessen, Germany \\ †Department of Animal Sciences, Chair of Animal Nutrition, Technical University of Munich, Liesel-Beckmann-Straße 6 , \\ D-85350 Freising-Weihenstephan, Germany
}

\begin{abstract}
This study was performed to investigate changes in expression level of genes involved in hepatic cholesterol metabolism in the transition from pregnancy to lactation and during different stages of lactation in dairy cows. Therefore, relative mRNA abundances of several genes involved in various pathways of cholesterol homeostasis in liver biopsy samples of 20 dairy cows, taken in late pregnancy (3 wk prepartum) and early lactation (1, 5, and 14 wk postpartum), were determined. At 1 wk postpartum, hepatic mRNA abundances of genes involved in cholesterol synthesis (3-hydroxy-3-methylglutaryl-coenzyme A reductase, mevalonate kinase, and farnesyl diphosphate synthase), cholesterol uptake from blood (low-density lipoprotein receptor), bile acid synthesis (cholesterol- $7 \alpha$-hydroxylase), cholesterol efflux [ATP-binding cassette (ABC) transporter A1 and $A B C G 1]$, esterification of cholesterol (acyl-coenzyme A:cholesterol acyltransferase), and proteins involved in assembly and secretion of very low-density lipoproteins (microsomal triglyceride transfer protein, ApoB100) were increased compared with 3 wk prepartum. The mRNA abundances of most of these genes decreased after 1 wk of lactation and reached levels in 5 and 14 wk of lactation similar to those at 3 wk prepartum. Only mRNA abundances of cholesterol- $7 \alpha$-hydroxylase, $\mathrm{ABC}$ transporters, and $A p o B 100$ remained at 5 and $14 \mathrm{wk}$ postpartum at levels higher than those at $3 \mathrm{wk}$ prepartum. Hepatic cholesterol abundance was highest at $1 \mathrm{wk}$ postpartum and was, thereafter, decreasing to values similar to that at 3 wk prepartum. Overall, this study shows that the onset of lactation is associated with an increased expression of various genes involved in cholesterol metabolism in the liver of dairy cows, suggesting that pronounced changes in hepatic cholesterol metabolism take place in the periparturient phase.
\end{abstract}

Received December 3, 2011.

Accepted March 12, 2012

${ }^{1}$ Corresponding author: klaus.eder@ernaehrung.uni-giessen.de
Key words: cholesterol, gene expression, dairy cow, transition period

\section{INTRODUCTION}

In dairy cows, the transition from late pregnancy to early lactation is associated with severe metabolic adaptations that aim to supply the organism with sufficient energy for milk production. During late pregnancy and lactation, energy requirements increase considerably in cattle, whereas DMI gradually decreases from 3 wk prepartum to parturition (Grummer, 1995; Ingvartsen and Andersen, 2000). During early lactation, dairy cows are typically in a negative energy balance, which leads to strong metabolic and hormonal changes (Goff and Horst, 1997; LeBlanc, 2010). Changes in lipid and glucose metabolism such as a strong induction of lipolysis in adipose tissue or the stimulation of gluconeogenesis and ketogenesis in the liver in the periparturient phase have been well documented (Loor et al., 2005; Kessel et al., 2008; Hammon et al., 2009; van Dorland et al., 2009; Graber et al., 2010). These metabolic changes are mediated by an altered secretion of various homeostatic and homeorhetic hormones (Ingvartsen and Andersen, 2000). In contrast, less information exists about potential alterations of hepatic cholesterol metabolism during the transition from late pregnancy to early lactation in dairy cows. In animal species other than cattle, such as rats, it has been shown that the onset of lactation is associated with pronounced changes in hepatic cholesterol metabolism, such as an increased formation of cholesterol and bile acids in the liver. For instance, it has been shown that cholesterol synthesis is strongly upregulated in early lactation in comparison to late pregnancy (Smith et al., 1998; Athippozhy et al., 2011). It has been suggested that this adaptation aims to increase the hepatic pool of cholesterol, which is required for an increased formation of bile acids, the formation of membranes in liver hypertrophy occurring during lactation, and for synthesis and secretion of lipoproteins to provide the mammary gland with cho- 
lesterol and triglycerides for milk production (Smith et al., 1998). It is likely that similar changes in cholesterol metabolism during the transition period occur in dairy cows. Hepatic cholesterol homeorhesis involves various biochemical pathways such as de novo synthesis of cholesterol, uptake of cholesterol from blood by low-density lipoprotein (LDL) receptors, secretion of cholesterol as very low-density lipoproteins (VLDL) into the blood, formation of bile acids, and cholesterol efflux into the blood by ATP-binding cassette (ABC) transporters (Chang et al., 2006). To investigate the hypothesis that the onset of lactation leads to pronounced alterations in cholesterol metabolism, we determined relative mRNA abundances of various genes involved in cholesterol synthesis and uptake [3-hydroxy-3-methylglutaryl CoA reductase $(\boldsymbol{H M G C R})$, mevalonate kinase $(\boldsymbol{M V K})$, farnesyl diphosphate synthase $(\boldsymbol{F D P S})$, and LDL receptor (LDLR)], esterification of cholesterol [acylCoA:cholesterol acyltransferase $(\boldsymbol{A C A T}) 1]$, assembly and secretion of VLDL [microsomal triglyceride transfer protein $(\boldsymbol{M T P})$ and apolipoprotein B100 (ApoB100)], bile acid formation [7- $\alpha$-cholesterol hydroxylase $(\boldsymbol{C} \boldsymbol{Y}$ $\boldsymbol{P 7 A 1 )}$, and cholesterol efflux ( $A B C A 1$ and $A B C G 1)$ in liver biopsy samples of dairy cows in the late pregnancy (3 wk prepartum) and early lactation (1, 5, and 14 wk postpartum).

\section{MATERIALS AND METHODS}

The animal experiment was performed at the Agricultural Experimental Station Hirschau of the Technical University of Munich, Germany. The Bavarian state animal care and use committee approved the study.

\section{Animals and Feeding}

Four primiparous and 16 multiparous Holstein cows $(2.7 \pm 1.1$ parities, mean $\pm \mathrm{SD})$ served as experimental animals. The experimental period involved the time span from 3 wk prepartum until 14 wk postpartum. The animals were housed in a playpen except for $\mathrm{d} 7$ before expected calving date until d 5 postpartum when they were kept apart from the herd in straw-bedded calving pens. A partial mixed ration consisting of (DM basis) $33.7 \%$ grass silage, $44.9 \%$ maize silage, $6.4 \%$ hay, and $14.9 \%$ concentrate was fed for ad libitum intake of basic feed. Furthermore, 2 kinds of concentrate were individually allocated to the animals. First, each cow received $0.63 \mathrm{~kg} / \mathrm{d}$ of supplemental concentrate, consisting of $24.4 \%$ soybean meal, $48.3 \%$ maize, and $27.3 \%$ rumen-protected fat supplement (DM basis) and given by hand once daily after milking. Additionally, each cow was enabled access to an individually allocated concentrate (24.8\% maize, $21.8 \%$ wheat, $20.1 \%$ soybean meal, $15.2 \%$ dried sugar beet pulp with molasses, $14.9 \%$ barley, and $3.2 \%$ vitamin-mineral premix (R-Lactol, Mineralfutter 2 für Rinder, RKW Süd, Würzburg, Germany) including limestone, DM basis) via 4 computeroperated feeding stations with an automatic feeding program (Alpro; DeLaval GmbH, Glinde, Germany). The allotted amount of this concentrate was increased from 1.2 to $8.0 \mathrm{~kg}$ of $\mathrm{DM} / \mathrm{d}$ during the first $42 \mathrm{~d}$ of lactation. Subsequently, the amount to be delivered to each cow was dependent on the individual milk performance. All provided feed components were sampled and analyzed for DM content, for crude nutrients crude ash, crude fiber, and crude fat (Naumann et al., 2000) as well as CP by the Dumas method (Schuster et al., 1991). The net energy content of the feedstuff (MJ of $\mathrm{NE}_{\mathrm{L}}$ ) and the available $\mathrm{CP}$ at the duodenum were calculated according to the German Society of Nutrition Physiology (GfE, 2001). Table 1 presents nutrient concentrations and energy contents of the used feed components.

\section{Sample Collection}

Twice daily (0500 and $1500 \mathrm{~h}$ ), lactating cows were milked in a $2 \times 6$ herringbone milking parlor (DeLaval $\mathrm{GmbH}$ ) with automatic recording of individual milk yield and its storage in data files. Two times per week, representative milk samples $(50 \mathrm{~mL})$ of 1 evening and the next morning milking were taken and mixed proportionally according to the milk yields. Blood samples of the dammed vena jugularis were collected at wk 3 prepartum, and wk 1, 5, and 14 postpartum before

Table 1. Mean nutrient values of experimental feedstuff

\begin{tabular}{|c|c|c|c|}
\hline Item & Partial mixed ration & Supplemental concentrate & Concentrate \\
\hline Energy $^{1}\left(\mathrm{MJ}\right.$ of $\mathrm{NE}_{\mathrm{L}} / \mathrm{kg}$ of $\left.\mathrm{DM}\right)$ & 6.45 & 12.8 & 8.00 \\
\hline Crude fiber $(\mathrm{g} / \mathrm{kg}$ of $\mathrm{DM})$ & 214 & 69 & 67 \\
\hline Crude ash $(\mathrm{g} / \mathrm{kg}$ of $\mathrm{DM})$ & 81 & 49 & 72 \\
\hline Crude fat $(\mathrm{g} / \mathrm{kg}$ of $\mathrm{DM})$ & 32 & 303 & 20 \\
\hline $\mathrm{CP}(\mathrm{g} / \mathrm{kg}$ of $\mathrm{DM})$ & 129 & 140 & 184 \\
\hline Available $\mathrm{CP}^{1}$ (g/kg of DM) & 142 & 151 & 187 \\
\hline
\end{tabular}

${ }^{1}$ Calculated values. 
morning feeding (between 0730 and 0900 h). For collection, sterile $20 \mathrm{G}$ cannulas and lithium heparin tubes (Greiner Bio-One GmbH, Kremsmünster, Austria) were used. Tubes were kept on ice and centrifuged $(2,000 \times$ $g$ for $15 \mathrm{~min}$ ) to obtain plasma, which was conveyed in 1.5-mL tubes (Greiner Bio-One GmbH, Frickenhausen, Germany) for storage at $-20^{\circ} \mathrm{C}$. At 3 wk prepartum, and 1,5 , and 14 wk postpartum, liver biopsy samples from each cow were taken. This procedure was conducted before morning feeding between 0700 and $0900 \mathrm{~h}$. Cows were isolated and bound on the self-locking feed fence. The liver biopsy site is located on the right side of the cow between the 11th and 12th ribs on a line between the olecranon and the tuber coxae. It was shaved and disinfected before it was locally anesthetized through subcutaneous injection of $5 \mathrm{~mL}$ of Isocaine $2 \%$ (procaine hydrochloride/epinephrine; Selectavet Dr. Otto Fischer GmbH, Weyarn/Holzolling, Germany). A sterile 14G biopsy needle (Dispomed Witt oHG, Gelnhausen, Germany) was introduced through an autoclaved cannula to withdraw about $50 \mathrm{mg}$ of liver tissue, which was immediately snap frozen in liquid nitrogen. Storage was at $-80^{\circ} \mathrm{C}$ until further analysis. Cows were treated with wound spray and stayed separated for another day.

\section{Sample Analysis}

Milk samples analyses were conducted by infrared spectrophotometry using a MilkoScan FT6000 (Foss Analytical A/S, Hillerød, Denmark) at the laboratory of Milchprüfring Bayern e.V. (Wolnzach, Germany). A mixture of n-hexane and isopropanol $(3: 2, \mathrm{vol} / \mathrm{vol})$ was used to extract lipids from liver tissue (Hara and Radin, 1978). According to De Hoff et al. (1978), aliquots of these lipid extracts were dried and the lipids dissolved using a 1:1 mixture of chloroform and Triton X-100. Cholesterol concentrations in liver lipid extracts as well as in thawed plasma samples were analyzed using a commercially available enzymatic kit (Fluitest CHOL; Analyticon Biotechnologies AG, Lichtenfels, Germany).

\section{Energy Balance}

For every individual cow, average daily energy balance was determined. For that, BW of the cows were noted automatically daily by electronic scales in 2 of the feeding stations. Dependent on the weekly mean BW of the cows, energy requirements for maintenance for each cow were calculated in line with the German Society of Nutrition Physiology (GfE, 2001). Furthermore, energy requirements for milk production were determined by means of weekly average daily milk yield, milk protein content, and milk fat content (GfE, 2001). Require- ments were contrasted with energy intake, which was calculated from the mean daily intakes of partial mixed ration and the concentrates and the associated energy contents $\left(\mathrm{MJ}\right.$ of $\mathrm{NE}_{\mathrm{L}}$ ). Variances in body composition were not considered in energy balance calculation.

\section{RNA Isolation and Real-Time Quantitative PCR}

Ribonucleic acid isolation from $10 \mathrm{mg}$ of liver tissue from each cow was conducted using TRIzol reagent (Invitrogen, Karlsruhe, Germany) according to the manufacturer's protocol. Isolation was performed within 1 wk after finishing the trial, whereupon RNA was stored at $-80^{\circ} \mathrm{C}$. Using an Infinite $200 \mathrm{M}$ microplate reader and a NanoQuant Plate (both from Tecan Group Ltd., Männedorf, Switzerland), the optical density at 260 and $280 \mathrm{~nm}$, respectively, was measured to evaluate RNA abundance and purity. The A260/A280 ratios were $1.96 \pm 0.05$ (means $\pm \mathrm{SD}$ ). In addition, the optical density at $230 \mathrm{~nm}$ was determined and the A260/A230 ratios were calculated to control for the presence of contaminations, such as guanidine thiocyanate. Although the A260/A230 ratio of some samples was below 2.0, indicating the presence of guanidine thiocyanate, it has been shown that guanidine thiocyanate has no measurable effect on downstream applications such as realtime quantitative PCR (qPCR) up to concentrations of more than $100 \mathrm{~m} M$ (von Ahlfen and Schlumpberger, 2010). Moreover, RNA quality was assessed by $1 \%$ agarose gel electrophoresis. Ribonucleic acid was judged as suitable only if the samples exhibited intact bands corresponding to the $18 \mathrm{~S}$ and $28 \mathrm{~S}$ ribosomal RNA subunits. Synthesis of cDNA from $1.2 \mu \mathrm{g}$ of total RNA was conducted using 100 pmol of dT18 primer (Eurofins MWG Operon, Ebersberg, Germany), $1.25 \mu \mathrm{L} 10$ mmol/L of dNTP mix (GeneCraft GmbH, Lüdinghausen, Germany), $5 \mu \mathrm{L}$ of buffer (Fermentas GmbH, St. Leon-Rot, Germany), and 60 units M-MuLV Reverse Transcriptase (MBI Fermentas GmbH, St. Leon-Rot, Germany) at $42^{\circ} \mathrm{C}$ for $60 \mathrm{~min}$, and a final inactivating step at $70^{\circ} \mathrm{C}$ for 10 min in a Biometra Thermal Cycler (Whatman Biometra GmbH, Göttingen, Germany). The cDNA was stored at $-20^{\circ} \mathrm{C}$. A standard curve was created using a cDNA pool of all samples. For performance of qPCR, $2 \mu \mathrm{L}$ of cDNA was used together with $18 \mu \mathrm{L}$ of a mixture composed of $10 \mu \mathrm{L}$ of KAPA SYBR FAST qPCR Universal Master Mix (Peqlab Biotechnologie $\mathrm{GmbH}$, Erlangen, Germany), $0.4 \mu \mathrm{L}$ each of 10 $\mu M$ forward and reverse primers, and $7.2 \mu \mathrm{L}$ of DNase/ RNase-free water in 0.1-mL tubes (LTF Labortechnik GmbH \& Co. KG, Wasserburg, Germany). Sequences for primer pairs specific for $L X R \alpha, A B C A 1$, and $A B C G 1$ were obtained from Mani et al. (2010). Further 
gene-specific primer pairs were created using Primer3 (http://frodo.wi.mit.edo/) and BLAST (http://blast. ncbi.nlm.nih.gov/Blast.cgi) and were obtained from Eurofins MWG Operon (Ebersberg, Germany). Characteristics of primer pairs are listed in Table 2. Annealing temperatures of all primer pairs were near $60^{\circ} \mathrm{C}$. Wherever possible, matching primers were designed to be located in different exons. A Rotor-Gene 2000 system (Corbett Research Pty Ltd., Mortlake, Australia) was used to perform qPCR runs, which included all samples and a 5-point relative standard curve as well as the nontemplate control (NTC) according to the following protocol: $3 \mathrm{~min}$ at $95^{\circ} \mathrm{C}$, followed by 40 cycles of a 2-step PCR consisting of $5 \mathrm{~s}$ at $95^{\circ} \mathrm{C}$ (denaturation) and $20 \mathrm{~s}$ at $60^{\circ} \mathrm{C}$ (annealing and extension). To ascertain the presence of a single PCR product, melting curve analysis was performed from 50 to $95^{\circ} \mathrm{C}$. Additionally, the amplification of a single product of the expected size was approved using $2 \%$ agarose gel electrophoresis stained with GelRed nucleic acid gel stain (Biotium Inc., Hayward, CA). Data on qPCR performance for genes measured are listed in Table 2. Reference gene stability was determined by GeNorm analysis (Vandesompele et al., 2002) using the reference gene-stability measure $M$. Then, the GeNorm normalization factor was calculated from the 3 reference genes showing the lowest $M$ values, indicating the most stable expression out of 6 tested potential reference genes [most stable reference genes: ribosomal protein L12 (RPL12), peptidylprolyl isomerase A (PPIA), ATP synthase, $\mathrm{H}^{+}$transporting, mitochondrial F1 complex, and $\beta$ polypeptide $(A T P 5 B)]$. Cycle threshold $(\mathrm{Ct})$ values were converted into relative quantification data by using the $2^{-\Delta \Delta \mathrm{Ct}}$ equation (Livak and Schmittgen, 2001). Afterward, relative expression levels were calculated using the GeNorm normalization factor. Normalized expression data were then expressed as means and standard deviations for samples of the same lactation week. Relative expression ratios of 1,5 , and $14 \mathrm{wk}$ postpartum are expressed as fold changes compared with 3 wk prepartum after setting the mean of 3 wk prepartum to 1 .

\section{Statistics}

Data were statistically evaluated by one-way ANOVA with time point of sampling as factor, using the Minitab Statistical Software Release 13.0 (Minitab Inc., State College, PA). Prior to statistical analysis, all data were checked for normality and outliers before statistical analysis. The significances of differences between the groups over time were analyzed by Fisher's multiple range test. Differences were regarded as significant for $P<0.05$.

\section{RESULTS}

\section{DMI, Performance, and Energy Balance in Dairy Cows in the Transition Period and at Different Stages of Lactation}

Dry matter intake of the cows 1 wk postpartum was similar to that at $3 \mathrm{wk}$ prepartum and increased thereafter toward 5 and 14 wk postpartum (Table 3). The onset of lactation led to a strong negative energy balance. Energy balance was most strongly negative at 1 wk postpartum, and improved thereafter. At 14 wk postpartum, the cows returned to a slightly positive energy balance (Table 3). Milk yield increased from 1 to $5 \mathrm{wk}$ postpartum and decreased thereafter to $14 \mathrm{wk}$ postpartum. Milk fat and milk protein contents were highest at 1 wk postpartum and were decreased thereafter (Table 3).

\section{Relative mRNA Abundances of Hepatic Genes Involved in Cholesterol Synthesis and Cellular Uptake}

Relative mRNA abundances of various genes involved in cholesterol synthesis (HMGCR, FDPS, and $M V K)$ and cholesterol uptake $(L D L R)$ in the liver were increased from 3 wk prepartum to 1 wk postpartum $(P<0.05$; Figure 1). From 1 wk postpartum to 5 and 14 wk postpartum, mRNA abundances of these genes decreased. The mRNA abundances of $H M G C R$ and $L D L R$ at 5 and 14 wk postpartum were similar to those at $3 \mathrm{wk}$ prepartum (Figure 1). In contrast, mRNA abundances of FDPS and $M V K$ at 5 and $14 \mathrm{wk}$ postpartum were higher than those at 3 wk prepartum $(P<0.05 ;$ Figure 1$)$. The mRNA abundance of sterol regulatory element-binding protein $2(\boldsymbol{S R} \boldsymbol{E} \boldsymbol{B P}$-2) in the liver was not different between 3 wk prepartum and the different stages of lactation considered (Figure 1).

\section{Relative mRNA Abundances of Hepatic Genes Involved in Bile Acid Synthesis and Cholesterol Efflux}

Relative mRNA abundances of liver $\mathrm{X}$ receptor $(L X R)-\alpha$ and its target genes involved in bile acid formation (CYPrA1) and cholesterol efflux ( $A B C A 1$ and $A B C G 1)$ in the liver were upregulated from 3 wk prepartum to $1 \mathrm{wk}$ postpartum $(P<0.05$; Figure 2$)$. The mRNA abundances of $L X R \alpha, C Y P 7 A 1$, and $A B C A 1$ at 5 and 14 wk postpartum remained at a level similar to that at $1 \mathrm{wk}$ postpartum (Figure 2). The mRNA abundance of $A B C G 1$ increased even further from $1 \mathrm{wk}$ to 5 and 14 wk postpartum $(P<0.05$; Figure 2$)$. 
Table 2. Characteristics and performance data of the primers used for reference gene-stability measure $M$ and real-time quantitative PCR analysis

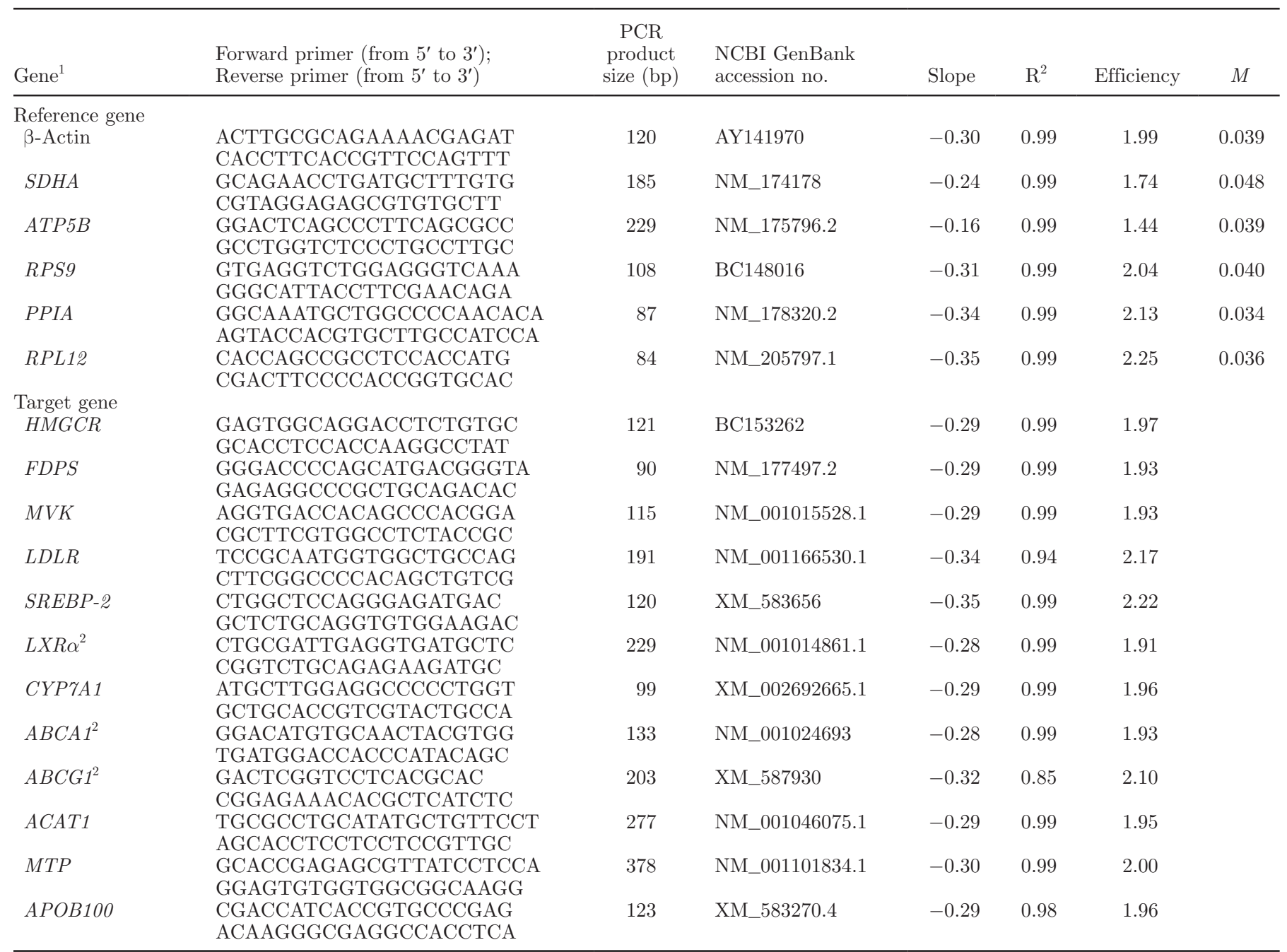

${ }^{1} S D H A=$ succinate dehydrogenase complex, subunit $\mathrm{A} ; A T P 5 B=$ ATP synthase, $\mathrm{H}^{+}$transporting, mitochondrial F1 complex, $\beta$ polypeptide; $R P S 9=$ ribosomal protein S9; PPIA = peptidylprolyl isomerase A; RPL12 = ribosomal protein L12; HMGCR = 3-hydroxy-3-methylglutaryl $\mathrm{CoA}$ reductase; FDPS = farnesyl diphosphate synthase; $M V K=$ mevalonate kinase; $L D L R=$ low-density lipoprotein receptor; $S R E B P-2=$ sterol regulatory element-binding protein $2 ; L X R \alpha=$ liver $\mathrm{X}$ receptor $\alpha ; C Y P 7 A 1=7$ - $\alpha$-cholesterol hydroxylase; $A B C A 1=\mathrm{ATP}$-binding cassette, subfamily A, member 1; ABCG1 = ATP-binding cassette, subfamily G, member 1; ACAT1= acyl-CoA:cholesterol acyltransferase; MTP $=$ microsomal triglyceride transfer protein; $A P O B 100=$ apolipoprotein $\mathrm{B} 100$.

${ }^{2}$ Primer sequences according to Mani et al. (2010).

Table 3. Performance of dairy cows in the transition period and at different stages of lactation ${ }^{1}$

\begin{tabular}{|c|c|c|c|c|c|c|}
\hline Variable & $\begin{array}{c}3 \mathrm{wk} \\
\text { prepartum }\end{array}$ & $\begin{array}{c}1 \mathrm{wk} \\
\text { postpartum }\end{array}$ & $\begin{array}{c}5 \mathrm{wk} \\
\text { postpartum }\end{array}$ & $\begin{array}{c}14 \mathrm{wk} \\
\text { postpartum }\end{array}$ & $\begin{array}{l}\text { wk } 1 \text { to } 14 \\
\text { postpartum }\end{array}$ & $P$-value \\
\hline DMI (kg/d) & $13.4 \pm 1.36^{\mathrm{c}}$ & $13.4 \pm 1.26^{\mathrm{c}}$ & $18.4 \pm 2.78^{\mathrm{b}}$ & $20.4 \pm 2.37^{\mathrm{a}}$ & $18.5 \pm 3.37$ & $<0.001$ \\
\hline Milk yield $(\mathrm{kg} / \mathrm{d})$ & - & $28.6 \pm 3.42^{\mathrm{c}}$ & $37.5 \pm 4.00^{\mathrm{a}}$ & $32.0 \pm 3.60^{\mathrm{b}}$ & $32.7 \pm 5.18$ & $<0.001$ \\
\hline Milk fat (\%) & - & $6.40 \pm 1.13^{\mathrm{a}}$ & $4.51 \pm 0.91^{\mathrm{b}}$ & $4.11 \pm 0.57^{\mathrm{b}}$ & $5.00 \pm 1.34$ & $<0.001$ \\
\hline Milk protein (\%) & - & $4.09 \pm 0.40^{\mathrm{a}}$ & $2.85 \pm 0.23^{\mathrm{c}}$ & $3.13 \pm 0.26^{\mathrm{b}}$ & $3.35 \pm 0.61$ & $<0.001$ \\
\hline Energy balance $^{3}\left(\mathrm{MJ}\right.$ of $\left.\mathrm{NE}_{\mathrm{L}} / \mathrm{d}\right)$ & $46.9 \pm 10.3^{\mathrm{a}}$ & $-64.9 \pm 22.5^{\mathrm{d}}$ & $-30.4 \pm 12.6^{\mathrm{c}}$ & $3.89 \pm 7.88^{\mathrm{b}}$ & $-12.5 \pm 45.6$ & $<0.001$ \\
\hline
\end{tabular}

\footnotetext{
${ }^{\mathrm{a}-\mathrm{d}}$ Means within rows with different superscript letters differ significantly $(P<0.05)$.

${ }^{1}$ Values are means $\pm \mathrm{SD}(\mathrm{n}=20)$.

${ }^{2}$ Corrected for $4 \%$ milk fat content.

${ }^{3}$ Calculated value.
} 
HMGCR

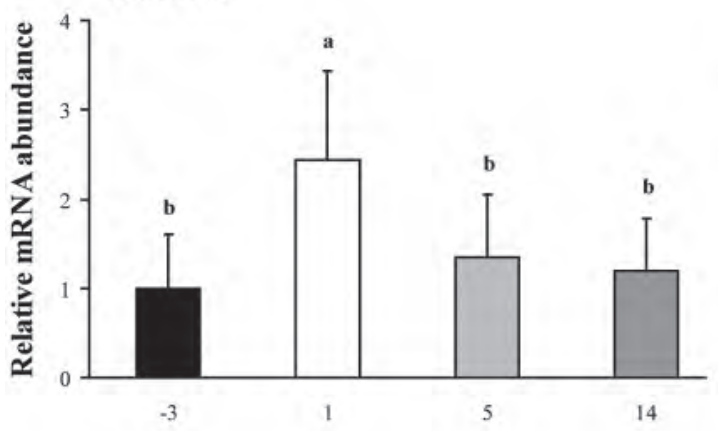

FDPS

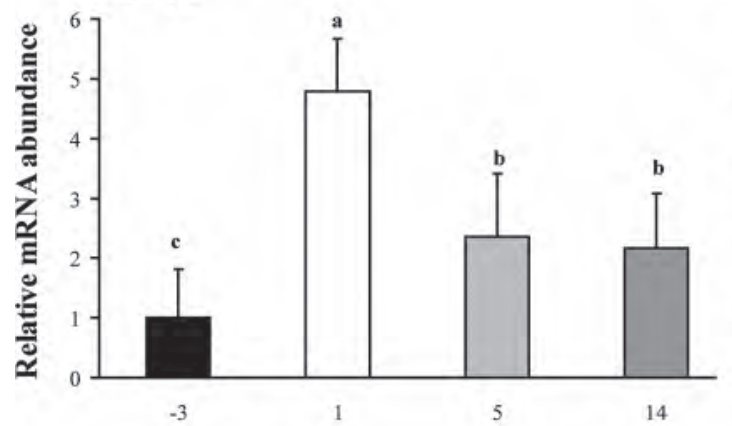

MVK

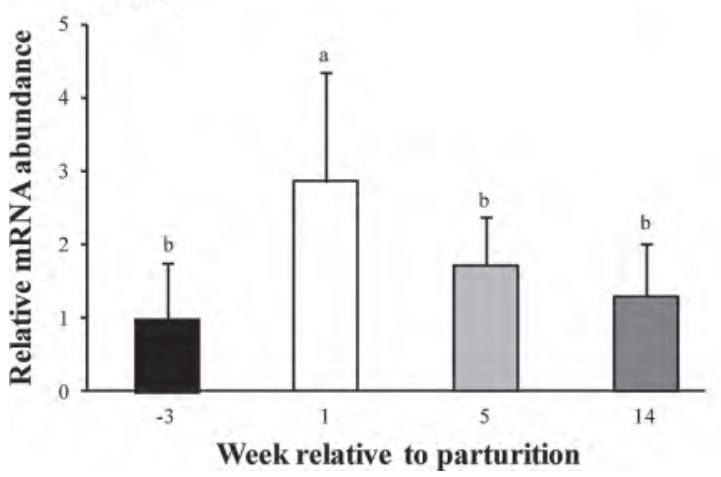

LDLR

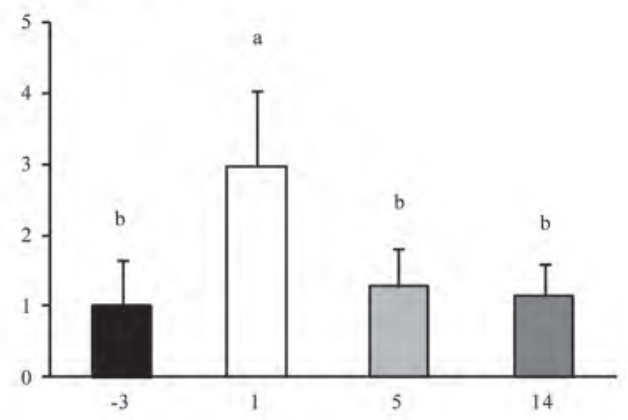

SREBP-2

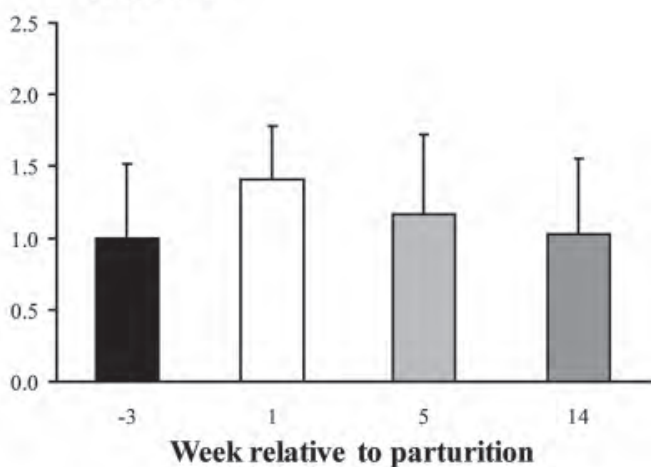

Figure 1. Relative mRNA abundances of hepatic genes involved in cholesterol synthesis [3-hydroxy-3-methylglutaryl (HMG)-CoA reductase $(H M G C R)$, farnesyl diphosphate synthase (FDPS), and mevalonate kinase $(M V K)$ ] and cellular uptake [low-density lipoprotein receptor $(L D L R)]$ and sterol regulatory element binding protein $2(S R E B P-2)$ in the liver of dairy cows in the transition period and early stages of lactation; bars represent means $\pm \mathrm{SD}(\mathrm{n}=20)$ and are expressed relative to the mRNA abundance at 3 wk prepartum. Bars with different letters $(\mathrm{a}, \mathrm{b}$, and $\mathrm{c})$ differ significantly $(P<0.05)$.

\section{Relative mRNA Abundances of Hepatic Genes Involved in Esterification of Cholesterol and Assembly and Secretion of VLDL}

Relative mRNA abundances of $A C A T 1, M T P$, and $A p o B 100$ in the liver were increasing from $3 \mathrm{wk}$ prepartum to 1 wk postpartum $(P<0.05$; Figure 3$)$. The mRNA abundance of $A p o B 100$ at 5 and 14 wk postpartum remained at a level similar to that at 1 wk postpartum (Figure 3). In contrast, mRNA abundances of $A C A T 1$ and MTP decreased from 1 wk postpartum to 5 and 14 wk postpartum (Figure 3 ). The mRNA abun- dance of $A C A T 1$ at 5 and 14 wk postpartum, however, remained in excess of that observed at 3 wk prepartum $(P<0.05 ;$ Figure 3$)$. The mRNA abundances of $M T P$ at 5 and 14 wk postpartum returned to a level similar to that observed at $3 \mathrm{wk}$ prepartum (Figure 3).

\section{Concentration of Cholesterol in Liver and Plasma}

Liver cholesterol concentration increased from $3 \mathrm{wk}$ prepartum to 1 wk postpartum and decreased thereafter $(P<0.05$; Figure 4$)$. Liver cholesterol concentration at 14 wk postpartum was similar to that observed at $3 \mathrm{wk}$ 

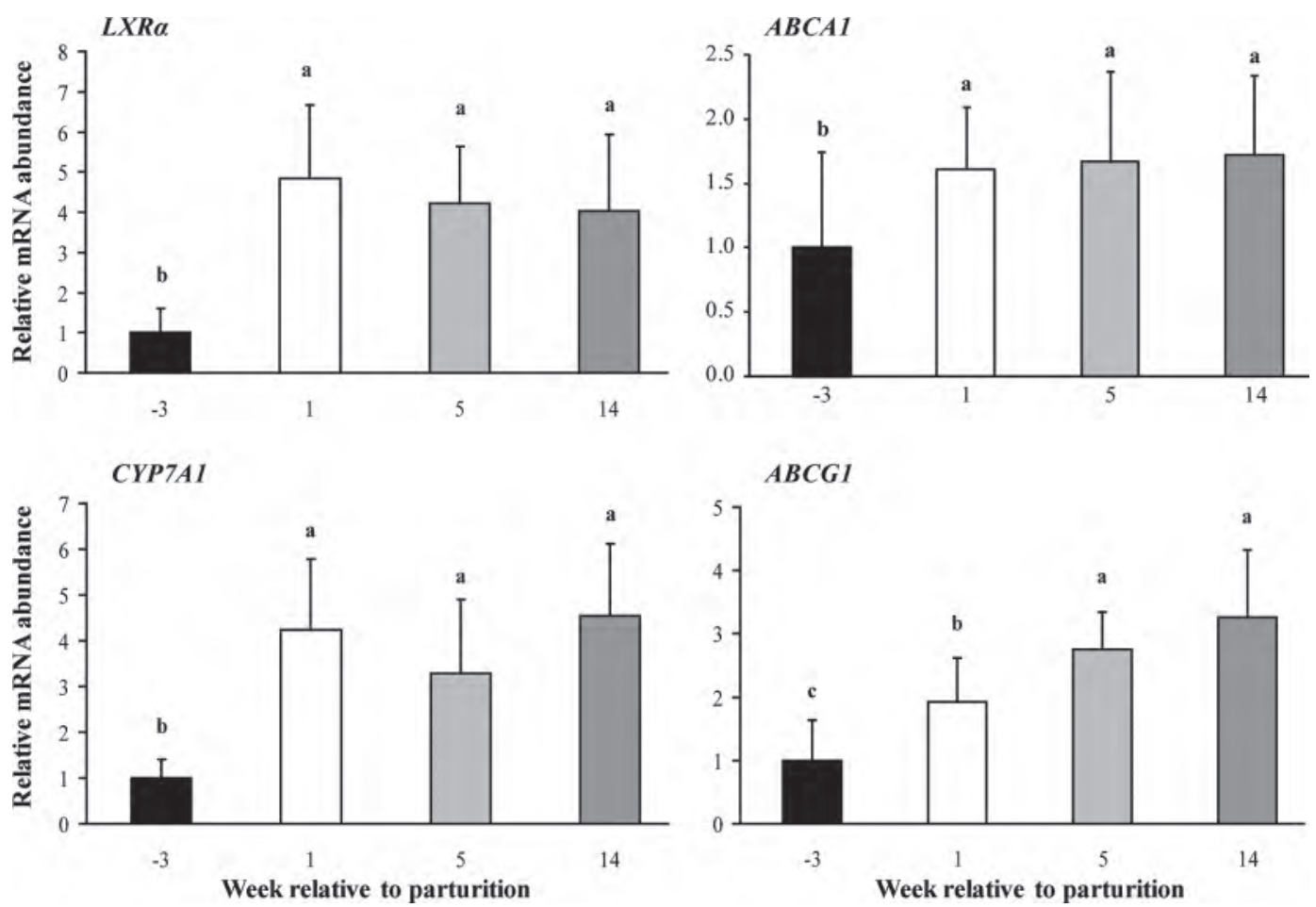

Figure 2. Relative mRNA abundances of liver X receptor $\alpha(L X R \alpha)$ and its target genes involved in bile acid formation $[7-\alpha-c h o l e s t e r o l$ hydroxylase $\left(C Y Y^{7}\right.$ 71) $]$ and cholesterol efflux [ATP-binding cassette, subfamily A, member 1 (ABCA1); ATP-binding cassette, subfamily G, member $1(A B C G 1)]$ in the liver of dairy cows in the transition period and early stages of lactation. Bars represent means \pm SD $(\mathrm{n}=20)$ and are expressed relative to the mRNA abundance at $3 \mathrm{wk}$ prepartum. Bars with different letters $(\mathrm{a}, \mathrm{b}$, and $\mathrm{c})$ differ significantly $(P<0.05)$.

prepartum (Figure 4). Plasma cholesterol concentration decreased from 3 wk prepartum to 1 wk postpartum and increased thereafter $(P<0.05$; Figure 4$)$. Plasma cholesterol concentrations at 5 and 14 wk postpartum were in excess of that observed at 3 wk prepartum $(P$ $<0.05$; Figure 4$)$.

\section{DISCUSSION}

This study was performed to investigate the hypothesis that the onset of lactation in dairy cows leads to alterations in the expression of genes involved in hepatic cholesterol homeorhesis. To investigate this hypothesis, we determined mRNA abundances of genes involved in various pathways of cholesterol metabolism in liver biopsy samples of cows at late pregnancy ( $3 \mathrm{wk}$ prepartum) and at various stages of lactation $(1,5$, and $14 \mathrm{wk}$ postpartum). As expected, the transition of the cows from late pregnancy to early lactation was associated with a strong negative energy balance.

Cholesterol synthesis in the liver and uptake of cholesterol from the blood via LDLR are controlled by SREBP-2, which belongs to the SREBP family, transcription factors that have been identified as key regulators of lipid synthesis and homeostasis (Brown and Goldstein, 1997). The SREBP are synthesized as inactive integral endoplasmic reticulum membrane proteins and are activated by proteolytic cleavages in the Golgi releasing the mature N-terminal domain of SREBP, which translocates to the nucleus and activates transcription of its target genes. The present study shows that several SREBP-2 target genes involved in cholesterol synthesis are markedly upregulated in the transition from late pregnancy (3 wk prepartum) to early lactation (1 wk postpartum). Synthesis of cholesterol is mainly controlled at the level of transcription of HMGCR, the rate-limiting enzyme of cholesterol synthesis (Espenshade and Hughes, 2007). Although we did not measure the activity of that enzyme or in vivo cholesterol synthesis, the finding that this enzyme was upregulated suggests that hepatic cholesterol synthesis could have been stimulated at 1 wk postpartum. Moreover, we found an increase of mRNA abundance of $L D L R$ in the liver $1 \mathrm{wk}$ postpartum, suggesting that the uptake of cholesterol from blood into the liver via LDLR could have been increased in this early stage of lactation. For technical reasons (due to the small amount of liver biopsy sample available), we were not able to determine the concentration of the mature SREBP-2 protein in the nucleus. However, the finding 

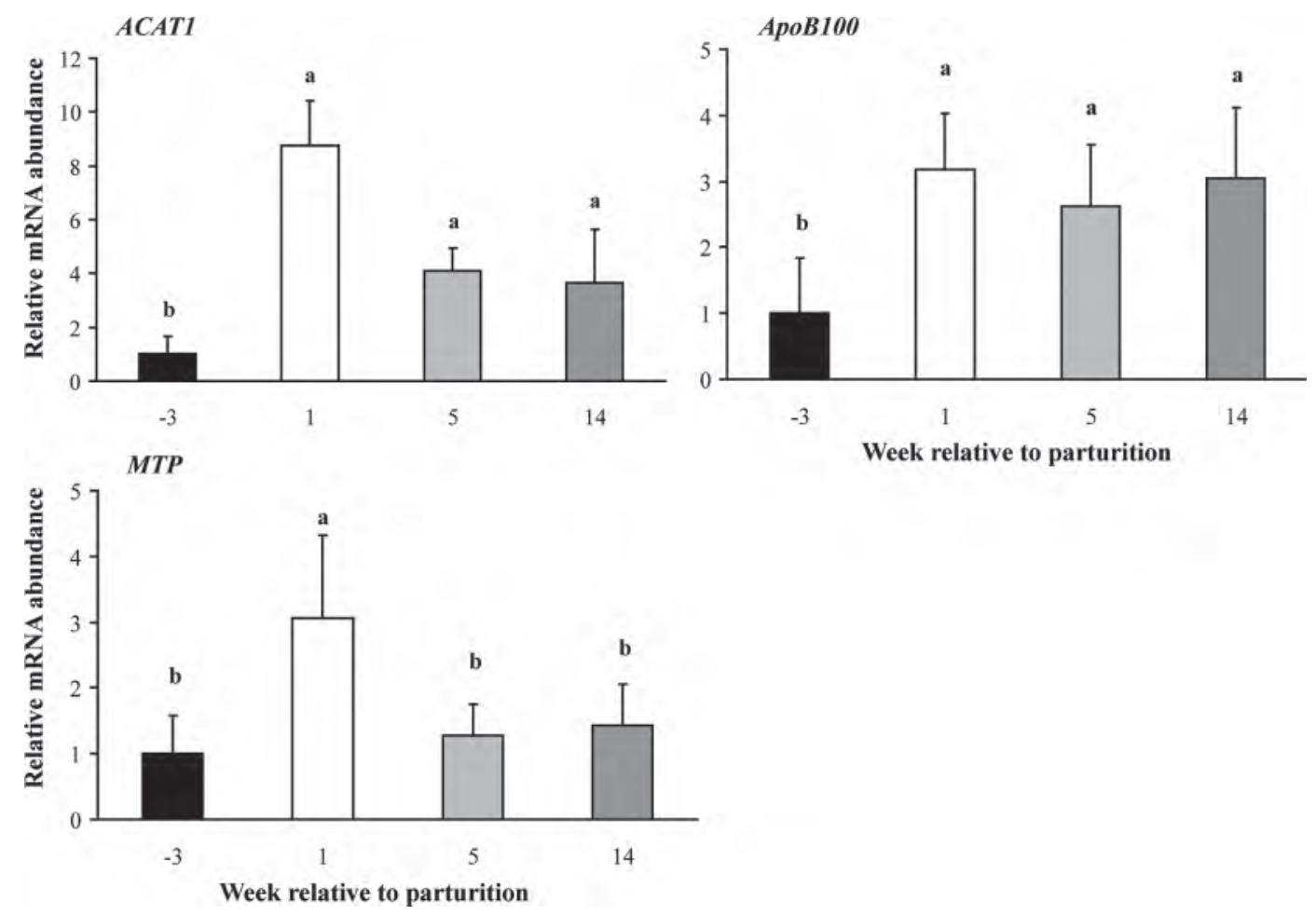

Figure 3. Relative mRNA abundances of acyl-CoA:cholesterol acyltransferase (ACAT1), microsomal triglyceride transfer protein (MTP), and apolipoprotein B 100 (ApoB100) in the liver of dairy cows in the transition period and early stages of lactation. Bars represent means \pm $\mathrm{SD}(\mathrm{n}=20)$ and are expressed relative to the mRNA abundance at 3 wk prepartum. Bars with different letters (a and b) differ significantly $(P<0.05)$.

that several SREBP-2 target genes, including enzymes of cholesterol synthesis and LDLR, were upregulated at 1 wk postpartum indicates that proteolytic activation of SREPB-2 was stimulated, leading to increased concentrations of the transcriptionally active mature SREBP-2 in the nucleus. As mRNA abundance of SREBP-2 in the liver was not different between late pregnancy and early lactation, it can be excluded that the enhanced expression of SREBP-2 target genes was caused by an increased synthesis of the immature protein in the endoplasmic reticulum. In the literature, few other reports exist dealing with the expression of enzymes involved in cholesterol synthesis in the liver of cows in late pregnancy and in lactation ( Viturro et al., 2009; Graber et al., 2010). In the study of Graber et al. (2010), mRNA abundances of genes coding for HMGCR and HMG-CoA synthase, another enzyme involved in cholesterol synthesis, were higher at $13 \mathrm{wk}$ postpartum than at $3 \mathrm{wk}$ prepartum or $4 \mathrm{wk}$ postpartum. In contrast, Viturro et al. (2009) observed a downregulation of genes coding for HMGCR and HMG-CoA synthase in the liver of cows immediately after parturition, followed by a significant upregulation of those enzymes, which reached its maximum on $4 \mathrm{wk}$ postpartum. Those authors suggested that the upregu- lation of hepatic genes involved in cholesterol synthesis is a physiologic means to meet the additional requirement of cholesterol secreted with the milk. Studies in rats also revealed an increased expression or activity of HMGCR and LDLR in the liver during early lactation (Smith et al., 1998; Athippozhy et al., 2011). The findings of these studies are in agreement with earlier data showing an overall increased cholesterol synthesis during lactation in rats (Feingold and Moser, 1985). The stimulation of cholesterol synthesis during lactation in rats has been suggested to be a means to cover an increased requirement of cholesterol resulting from enhanced bile acid synthesis; novel synthesis of membranes as a consequence of liver hypertrophy, which occurs during lactation; and from an enhanced export of cholesterol to the mammary gland as VLDL (Smith et al., 1998).

The formation of bile acids represents an important source of loss of cholesterol in the liver. Bile acid formation is controlled by CYP7A1, an enzyme transcriptionally regulated by LXR $\alpha$ (Peet et al., 1998; Chiang et al., 2001). In the present study, we observed that $C Y P^{7}$ A1 is upregulated during lactation, suggesting an increased hepatic formation of bile acids; $\mathrm{ABCA} 1$ and ABCG1 are 2 members of the ABC transporters, which 

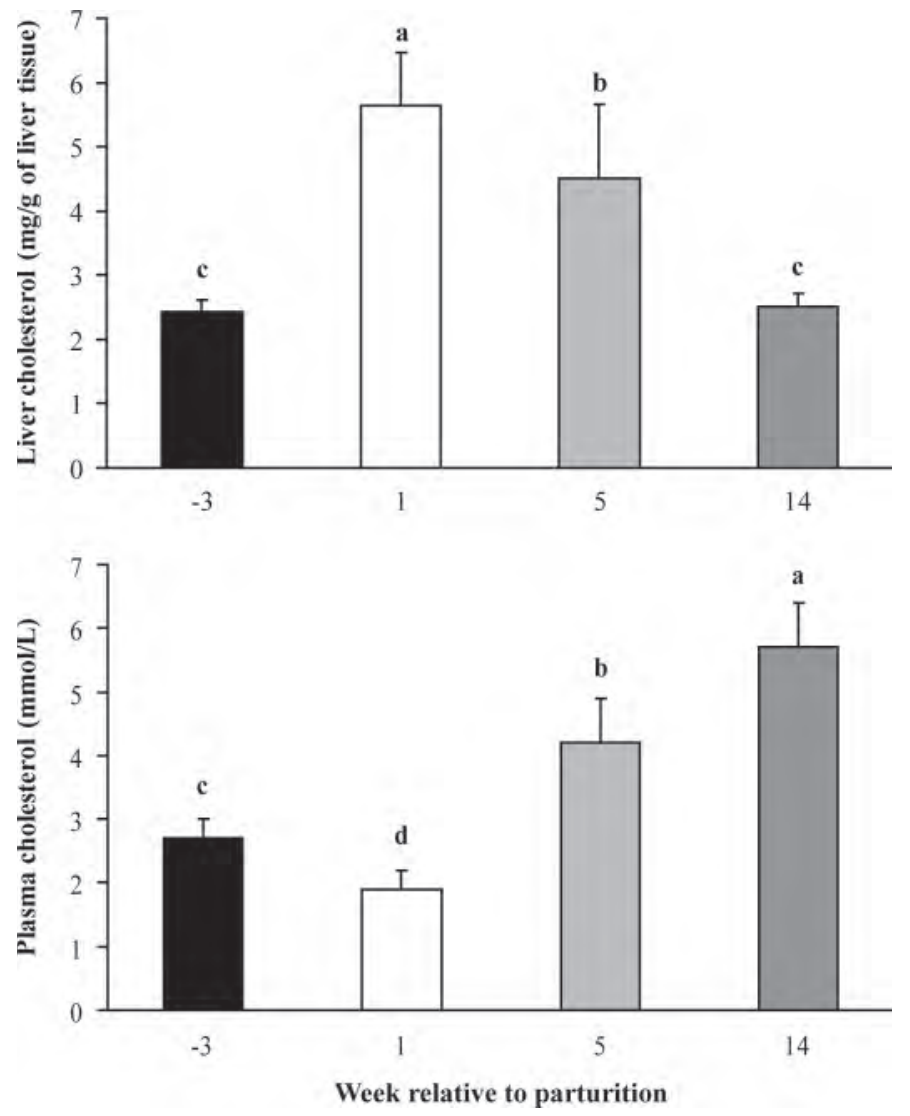

Figure 4. Cholesterol concentrations in plasma ( $\mathrm{mmol} / \mathrm{L})$ and liver tissue $(\mathrm{mg} / \mathrm{g}$ of liver tissue) from dairy cows in the transition period and early stages of lactation. Bars represent means $\pm \mathrm{SD}(\mathrm{n}=20)$ Bars with different letters (a, b, c, and d) differ significantly $(P<$ $0.05)$.

play an important role in the export of cholesterol from the cell. Both of these transporters are also target genes of LXR $\alpha$ (Li and Glass, 2004). We found that mRNA abundances of $A B C A 1$ and $A B C G 1$ were increased at all 3 points of time considered during lactation, indicative of an enhanced export of cholesterol. Likely, upregulation of $C Y P^{7} 7 A 1$ and the 2 cholesterol exporters was due the observed upregulation of $L X R \alpha$. It has been shown that LXR $\alpha$ acts as a sterol sensor that functions to help the cell to cope with high levels of free cholesterol (Repa and Mangelsdorf, 1999). Thus, it is possible the upregulation of $L X R \alpha$ and its target genes involved in bile acid formation and cholesterol export was induced by increased hepatic cholesterol levels, which might have been caused by an increased cholesterol synthesis and uptake of cholesterol by LDL observed in early lactation. To our knowledge, the expression of $L X R \alpha$ and its genes involved in bile acid synthesis and cholesterol export in dairy cows during lactation has not yet been investigated in other studies. The results of this study, however, are well in agreement with studies in rats, which also found an increased expression or activity of CYP7A1 in the liver during lactation (Smith et al., 1998; Wooton-Kee et al., 2010; Athippozhy et al., 2011). The upregulation of $C Y P^{7} 71$ has been attributed to an increased recruitment of LXR $\alpha$, which is in agreement with the present findings, and to a decreased expression of FGF15 and phosphorylated Erk1/2, which are acting as CYP7A1 repressive pathways (Wooton-Kee et al., 2010). It has been suggested that the elevated hepatic pool of bile acids, deriving from an increased bile acid formation due to upregulation of $C Y P^{7} 7 A 1$, is a physiologic means to enhance the absorption of lipids and lipid-soluble nutrients during lactation, which follows the aim of improving the supply with ME from the diet during the phase of strong negative energy balance (Wooton-Kee et al., 2010).

The enzyme ACAT catalyzes the esterification of free cholesterol in the liver. This step is important for maintaining the concentration of free cholesterol in cells at low levels. Moreover, esterification of cholesterol is required for the secretion of cholesterol as cholesterol esters via VLDL. It has been suggested that ACAT is acting as an endoplasmic reticulum cholesterol sensor. The activity of ACAT is controlled by the availability of cholesterol in its vicinity (Chang et al., 2006). In the present study, we found an upregulation of $A C A T$ in the liver during lactation, most pronounced at 1 wk postpartum. It is likely that the upregulation of $A C A T$ was due to an enhanced expression of proteins involved in cholesterol synthesis and LDL uptake. Although no other studies exist dealing with expression of $A C A T$ in the liver during lactation in dairy cows, the results of the present study agree with findings in rats, which show an increased activity of ACAT in early lactation (Smith et al., 1998). Cholesterol esters are secreted from the liver, together with triacylglycerols, as VLDL; MTP plays a key role in the formation and secretion of VLDL by catalyzing the transfer of lipids, including cholesterol esters, to nascent ApoB molecules (Hussain et al., 2003). An increased expression of MTP, in common with an increased expression of ApoB100, suggests an increased assembly and secretion of VLDL at 1 wk postpartum. As the expression of MTP was not increased in 5 and $14 \mathrm{wk}$ postpartum, it is likely that a potentially increased secretion of lipids via VLDL occurred only at the first few weeks of lactation. A potentially increased formation and secretion of VLDL in the liver during early lactation could be regarded as means to supply the mammary gland with triglycerides and cholesterol for milk production.

Hepatic cholesterol concentration is the result of synthesis of cholesterol and uptake of cholesterol into the liver and losses of cholesterol (by formation of bile acids, secretion of VLDL, and cholesterol efflux). The present 
study shows that the concentration of cholesterol in the liver clearly increased from $3 \mathrm{wk}$ prepartum to $1 \mathrm{wk}$ postpartum. This finding suggests that synthesis and uptake of cholesterol exceeded the amount of cholesterol that was lost by upregulation of bile acid formation, assembly and secretion of VLDL, and cholesterol efflux via ABC transporters. From 1 wk postpartum to later lactation, hepatic cholesterol concentration decreased, reaching values similar to that observed at late pregnancy. The decrease in plasma cholesterol concentration from early to later lactation might be due to the possibility that, according to mRNA abundances of $H M G C R$ and $L D L R$, hepatic cholesterol synthesis and uptake of cholesterol were enhanced exclusively before $5 \mathrm{wk}$ postpartum and were decreased thereafter to levels observed in late pregnancy. To our knowledge, liver cholesterol concentration in dairy cows during lactation has not yet been investigated in other studies. Changes of plasma cholesterol concentrations from late pregnancy to lactation are largely in agreement with those reported in other studies (Janovick Guretzky et al., 2006; van Dorland et al., 2009; Graber et al., 2010). In the study of van Dorland et al. (2009), the pattern of plasma cholesterol concentration followed that of hepatic expression of enzymes involved in cholesterol synthesis, indicating that plasma cholesterol concentration was mainly influenced by hepatic cholesterol synthesis. In contrast to that study, we did not observe a relationship between the expression of hepatic enzymes of cholesterol synthesis and plasma concentration of cholesterol. Indeed, plasma concentration of cholesterol was even lowest when expression of hepatic enzymes of cholesterol reached its maximum. We suspect that the low plasma cholesterol concentration at 1 wk postpartum could be due to the strong upregulation of $L D L R$, which is most important for the transport of cholesterol from blood into cells. At least in humans, an upregulation of $L D L$ is usually associated with a decrease in LDL and plasma cholesterol concentration (Fernandez and West, 2005).

\section{CONCLUSIONS}

The present study shows that the onset of lactation leads to pronounced alterations in the expression of various genes involved in cholesterol metabolism in the liver of dairy cows. These alterations include an increased expression of enzymes involved in cholesterol synthesis and uptake, an increased expression of the key enzyme of bile acid synthesis and of transporters involved in the efflux of cholesterol, and an increased expression of genes involved in esterification of cholesterol and assembly and secretion of VLDL. Most of these effects were attenuated or were completely disappeared during the course of lactation. Although we did not measure protein concentrations or activities of enzymes, these findings support that changes in cholesterol metabolism occur after the onset of lactation, which aim to supply the organism with sufficient cholesterol required for increased synthesis of bile acids and an export of cholesterol to the mammary gland for milk production.

\section{ACKNOWLEDGMENTS}

G. Schlegel was supported by a scholarship of H. Wilhelm Schaumann-Stiftung (Hamburg, Germany).

\section{REFERENCES}

Athippozhy, A., L. Huang, C. R. Wooton-Kee, T. Zhao, P. Jungsuwadee, A. J. Stromberg, and M. Vore. 2011. Differential gene expression in liver and small intestine from lactating rats compared to age-matched virgin controls detects increased mRNA of cholesterol biosynthetic genes. BMC Genomics 12:95.

Brown, M. S., and J. L. Goldstein. 1997. The SREBP pathway: Regulation of cholesterol metabolism by proteolysis of a membranebound transcription factor. Cell 89:331-340.

Chang, T.-Y., C. C. Y. Chang, N. Ohgami, and Y. Yamauchi. 2006. Cholesterol sensing, trafficking, and esterification. Annu. Rev. Cell Dev. Biol. 22:129-157.

Chiang, J. Y., R. Kimmel, and D. Stroup. 2001. Regulation of cholesterol $7 \alpha$-hydroxylase gene ( $\left.C Y P^{7} 7 A 1\right)$ transcription by the liver orphan receptor (LXR $\alpha)$. Gene 262:257-265.

De Hoff, J. L., L. M. Davidson, and D. Kritchevsky. 1978. An enzymatic assay for determining free and total cholesterol in tissue. Clin. Chem. 24:433-435.

Espenshade, P. J., and A. L. Hughes. 2007. Regulation of sterol synthesis in eukaryotes. Annu. Rev. Genet. 41:401-427.

Feingold, K. R., and A. H. Moser. 1985. Effect of lactation on cholesterol synthesis in rats. Am. J. Physiol. 249:G203-G208.

Fernandez, M. L., and K. L. West. 2005. Mechanisms by which dietary fatty acids modulate plasma lipids. J. Nutr. 135:2075-2078.

GfE (German Society of Nutrition Physiology). 2001. Empfehlungen zur Energie- und Nährstoffversorgung der Milchkühe und Aufzuchtrinder. DLG-Verlag, Frankfurt/Main, Germany.

Goff, J. P., and R. L. Horst. 1997. Physiological changes at parturition and their relationship to metabolic disorders. J. Dairy Sci. 80:1260-1268.

Graber, M., S. Kohler, T. Kaufmann, M. G. Doherr, R. M. Bruckmaier, and H. A. van Dorland. 2010. A field study on characteristics and diversity of gene expression in the liver of dairy cows during the transition period. J. Dairy Sci. 93:5200-5215.

Grummer, R. R. 1995. Impact of changes in organic nutrient metabolism on feeding the transition dairy cow. J. Anim. Sci. 73:2820 2833.

Hammon, H. M., G. Stürmer, F. Schneider, A. Tuchscherer, H. Blum, T. Engelhard, A. Genzel, R. Staufenbiel, and W. Kanitz. 2009. Performance and metabolic and endocrine changes with emphasis on glucose metabolism in high-yielding dairy cows with high and low fat content in liver after calving. J. Dairy Sci. 92:1554-1566.

Hara, A., and N. S. Radin. 1978. Lipid extraction of tissues with a low toxicity solvent. Anal. Biochem. 90:420-426.

Hussain, M. M., J. Shi, and P. Dreizen. 2003. Microsomal triglyceride transfer protein and its role in apoB-lipoprotein assembly. J. Lipid Res. 44:22-32.

Ingvartsen, K. L., and J. B. Andersen. 2000. Integration of metabolism and intake regulation: A review focusing on periparturient animals. J. Dairy Sci. 83:1573-1597. 
Janovick Guretzky, N. A., D. B. Carlson, J. E. Garrett, and J. K. Drackley. 2006. Lipid metabolite profiles and milk production for Holstein and Jersey cows fed rumen-protected choline during the periparturient period. J. Dairy Sci. 89:188-200.

Kessel, S., M. Stroehl, H. H. Meyer, S. Hiss, H. Sauerwein, F. J. Schwarz, and R. M. Bruckmaier. 2008. Individual variability in physiological adaptation to metabolic stress during early lactation in dairy cows kept under equal conditions. J. Anim. Sci. 86:2903-2912.

LeBlanc, S. 2010. Monitoring metabolic health of dairy cattle in the transition period. J. Reprod. Dev. 56:S29-S35.

Li, A. C., and C. K. Glass. 2004. PPAR- and LXR-dependent pathways controlling lipid metabolism and the development of atherosclerosis. J. Lipid Res. 45:2161-2173.

Livak, K. J., and T. D. Schmittgen. 2001. Analysis of relative gene expression data using real-time quantitative PCR and the $2^{-\Delta \Delta \mathrm{Ct}}$ method. Methods 25:402-408.

Loor, J. J., H. M. Dann, R. E. Everts, R. Oliveira, C. A. Green, N. A Janovick, S. L. Guretzky, H. A. Rodriguez-Zas, H. A. Lewin, and J. K. Drackley. 2005. Temporal gene expression profiling of liver from periparturient dairy cows reveals complex adaptive mechanisms in hepatic function. Physiol. Genomics 23:217-226.

Mani, O., M. Körner, M. T. Sorensen, K. Sejrsen, C. Wotzkow, C. E. Ontsouka, R. R. Friis, R. M. Bruckmaier, and C. Albrecht. 2010. Expression, localization, and functional model of cholesterol transporters in lactating and nonlactating mammary tissues of murine, bovine, and human origin. Am. J. Physiol. Regul. Integr. Comp. Physiol. 299:R642-R654.

Naumann, K., R. Basler, R. Seibold, and C. Barth. 2000. Die chemische Untersuchung von Futtermitteln, Methodenbuch Bd. III. Verband Deutscher Landwirtschaftlicher Untersuchungs- und Forschungsanstalten. VDLUFA-Press, Darmstadt, Germany.

Peet, D. J., B. A. Janowski, and D. J. Mangelsdorf. 1998. The LXRs: A new class of oxysterol receptors. Curr. Opin. Genet. Dev. 8:571-575.
Repa, J. J., and D. J. Mangelsdorf. 1999. Nuclear receptor regulation of cholesterol and bile acid metabolism. Curr. Opin. Biotechnol. 10:557-563.

Schuster, M., M. Morwarid, and H. Sattes. 1991. Verbrennungsmethode nach Dumas zur Bestimmung des Proteingehaltes in Futtermitteln. Verband Deutscher Landwirtschaftlicher Untersuchungsund Forschungsanstalten (VDLUFA)-Schriftenreihe 33:526-531.

Smith, J. L., S. R. Lear, T. M. Forte, W. Ko, M. Massimi, and S. K. Erickson. 1998. Effect of pregnancy and lactation on lipoprotein and cholesterol metabolism in the rat. J. Lipid Res. 39:2237-2249.

Vandesompele, J., K. De Preter, F. Pattyn, B. Poppe, N. Van Roy, A. De Paepe, and F. Speleman. 2002. Accurate normalization of realtime quantitative RT-PCR data by geometric averaging of multiple internal control genes. Genome Biol. 3:RESEARCH0034. http://dx.doi.org/10.1186/gb-2002-3-7-research0034.

van Dorland, H. A., S. Richter, I. Morel, M. G. Doherr, N. Castro, and R. M. Bruckmaier. 2009. Variation in hepatic regulation of metabolism during the dry period and in early lactation in dairy cows. J. Dairy Sci. 92:1924-1940.

Viturro, E., M. Koenning, A. Kroemer, G. Schlamberger, S. Wiedemann, M. Kaske, and H. H. D. Meyer. 2009. Cholesterol synthesis in the lactating cow: Induced expression of candidate genes. J. Steroid Biochem. Mol. Biol. 115:62-67.

von Ahlfen, S., and M. Schlumpberger. 2010. Effects of low A260/ A230 ratios in RNA preparations on downstream applications. QIAGEN Gene Expression Newsl. 15:6-7.

Wooton-Kee, C. R., D. J. Coy, A. T. Athippozhy, T. Zhao, B. R. Jones, and M. Vore. 2010. Mechanisms for increased expression of cholesterol $7 \alpha$-hydroxylase (Cyp7a1) in lactating rats. Hepatology $51: 277-285$. 